\title{
The Relationship between Hemoglobin Concentration and Physical Growth and Development of Toddlers Age 2-5 Years in Malacca Village, Sumedang, West Java, Indonesia
}

\author{
Nia Reviani ${ }^{1,2}$, Keswari Aji Patriawati ${ }^{3}$ \\ ${ }^{1}$ Medical Faculty, Universitas Kristen Indonesia, Jakarta, Indonesia \\ ${ }^{2}$ National Population and Family Planning Board, Republic of Indonesia \\ ${ }^{3}$ Department of Pediatrics, Medical Faculty, Universitas Kristen Indonesia, Jakarta, Indonesia
}

Corresponding Author: Nia Reviani

\begin{abstract}
Stunting is a chronic nutritional problem caused by insufficient nutritional intake for a long time and can disrupt growth and development. Besides affecting physical growth, stunting can also affect haemoglobin levels. Stunting children havelower haemoglobin levels than non-stunting toddlers. This study aims to determine the relationship between haemoglobin concentration and physical and developmental growth in children aged two years - 5 years in Malaka Village, Sumedang, West Java. This study used an Analytical Observational design with a cross-sectional study approach. The number of samples is 64 respondents. Sample selection was made by purposive sampling. Data collection was taken by measuring height and weight and using the Denver Developmental Screening Test II. Data is processed using the chi-square statistical test with a significance level of $\mathrm{p}(\alpha)=$ 0.05. The analysis results show no correlation between haemoglobin concentration and physical growth and development in children with asignificance value of $p>0.05$. It can be concluded that there is no significant relationship between haemoglobin concentration and physical and developmental growth in Infants 2 years - 5 years in Malaka Village, Sumedang. For further research, more respondents and better measurement tools are needed to improve theaccuracy of the research results.
\end{abstract}

Keyword: haemoglobin concentration, physical and developmental growth

\section{INTRODUCTION}

Children whose height measurement is below -2 Standard Deviation (SD) from the WHO standard are said to be short children (Stunting). Identify height by comparing a child's height with the height of children in the average population according to the same age and sex. Several current studies show that short children are strongly associated with poor education and lowerincome as adults. Stunting has a greater chance of growing into less educated, poorer, less healthy and more susceptible to infectious diseases [1]. The prevalence of stunting in Indonesia (29\%), according to
WHO stunting becomes a public health problem if the prevalence is more than 20 per cent (Infodatin Ministry of Health RI, 2016). Based on data from the Basic Health Research (Riskesdas) in 2013, it is known that the prevalence of stunting nationally is $37.2 \%$, which is an increase compared to 2010 (35.6\%) and 2007 (36.8\%). Based on national prevalence, out of 34 provinces in Indonesia, West Java ranks 26th (35.3\%). The prevalence of stunting in the Sumedang district in 2013 was $41.08 \%$, with the number of stunted children under five being 37,970 people [2]. In addition to affecting physical growth, stunting can also affect 
haemoglobin levels. Stunting toddlers have lower haemoglobin levels than non-stunted toddlers [3; 4]. Based on the background of the problem above, the formulation of this research problem is conceptualized in the form of a question, namely "Is there a relationship between haemoglobin concentration and physical growth of toddlers aged two years - 5 years in Malacca Village?" intending to know the relationship between haemoglobin concentration with physical growth and development of toddlers aged two years - 5 years in the village of Malacca.

\section{LITERATURE REVIEW}

Growth is a process of increasing size, both volume, weight, and the number of cells that are irreversible (cannot return to origin). Growth is related to changes in size, number, size, or dimensions at the level of cells, organs and individuals, as measured by weight, length, bone age, and metabolic balance (body calcium and nitrogen retention) $[5 ; 6]$. The way to measure the physical growth of children aged 0-6 years is to measure the child's height, weight, head circumference, and upper arm circumference and then compare it with the child's age. The measurement is carried out regularly $1 \mathrm{x} /$ month.

Development is the change or differentiation of cells to a more mature state. Development involves the process of differentiation of body cells, body tissues, organs and organ systems that develop so that each can fulfil its function, including emotional, intellectual and behavioural development as a result of interaction with the environment. Developmental events with growth occur synchronously because development is related to the maturation of organ/individual functions, while growth impacts physical aspects $[7 ; 8]$.

Development can be viewed from various aspects, namely: physical aspects (development can be in the form of gross motor and fine motor development), mental aspects (in the form of simple to complex thinking activities), emotional aspects (related to one's feelings such as fear, shame, disappointment), social aspect (is a person's ability to relate to other people).

To measure children aged 0-6 years, use the "Denver Development Test Screening II". Denver Test is a screening tool that must meet the validity, reliability, sensitivity, specificity, acceptability, and suitability to local conditions. Validity and reliability are parameters to determine the quality of the instrument, while sensitivity and specificity are measured by comparing developmental tests to the gold standard [9; 10].

Early detection of developmental deviations in children aged less than six years contains 125 task forces arranged into four sectors to encompass these functions. The aspects assessed include personal social (adjustment to society and attention to individual needs), fine motor (eye coordination, hand coordination, playing or using small objects), gross motor (sitting, walking, jumping, and general muscle movement), language (hearing, understanding, and using language) [11].

In interpreting this test, in each item, the examiner is required to enter a score for each question in all sectors. Where $\mathrm{P}=$ Pass, $\mathrm{F}=$ Fail, $\mathrm{R}=$ Refusal, $\mathrm{NO}=\mathrm{No}$ Opportunity. The interpretation results for the actual test are categorized into three parts. These sections include a) Normal If there is no "Late" score and 1 "Warning" (1 C). If these results are obtained, do a reexamination at the next visit; b) Suspected/suspected delay If there is one score "Late" and 2 "Warning". It must be caused by Fail (F), not due to rejection (R). If these results are obtained, retest in the next 1-2 weeks to eliminate temporary factors, such as fear, pain or fatigue; and c) Cannot be tested if there is one score "Late" and 2 "Warning". Note, in this case, and it must be due to rejection (R), not due to failure (F). If these results are obtained, do a retest in the next 1-2 weeks.

The name haemoglobin is a combination of the words hemin and globin. Haemoglobin is a protein in red blood cells 
that has the function of carrying oxygen throughout the body $[12 ; 13 ; 14]$. Haemoglobin levels according to WHO are: a) children six months to 6 years is $11 \mathrm{~g} / \mathrm{dL}$; b) children six years to 14 years, namely 12 $\mathrm{g} / \mathrm{dL}$; c) adult male, namely $13 \mathrm{~g} / \mathrm{dL} ; \mathrm{d}$ ) pregnant women, namely $11 \mathrm{~g} / \mathrm{dL}$; and e) adult women, which is $12 \mathrm{~g} / \mathrm{dL}$. Haemoglobin synthesis requires the coordinated production of heme and globin. Heme is a prosthetic group that mediates the reversible binding of oxygen to haemoglobin. Globin is a protein that surrounds and protects the heme molecule [15].

The formation of haemoglobin requires the coordinated production of heme and globin. Heme is a prosthetic group consisting of iron atoms, while globin is a protein that is broken down into amino acids. Heme is synthesized in a complex series of steps involving enzymes in the mitochondria and the cell cytosol. The first step in heme synthesis occurs in the mitochondria, with the condensation of succinyl CoA and glycine by ALA synthase to form 5-aminolevulinic acid [16; 17]. This molecule is transported to the cytosol, where a series of reactions result in a ring structure called coproporphyrinogen III. This molecule returns to the mitochondrion, where the addition reaction produces protoporphyrin IX.

The enzyme ferrochelatase inserts iron into the ring structure of protoporphyrin IX to produce heme. Defective heme production results in various anaemias. Iron deficiency, the most common cause of anaemia, impairs heme synthesis, resulting in anaemia. Several drugs and toxins directly inhibit heme production by interfering with enzymes involved in heme biosynthesis [18]. Lead generally produces significant anaemia by inhibiting heme synthesis, especially in children.

Hemoglobin is a spherical molecule consisting of 4 subunits. Each subunit contains a heme moiety conjugated to a polypeptide. Heme is an iron-containing porphyrin derivative $[19 ; 20]$. These polypeptides are collectively referred to as the globin portion of the haemoglobin molecule. The functions of haemoglobin in the body are a) Hemoglobin functions as an oxygen carrier; b) Hemoglobin functions as a carrier of carbon dioxide; c) Hemoglobin gives blood its red colour; d) Hemoglobin functions as a buffer in the body, and e) Destruction of haemoglobin accumulates physiologically active metabolites.

Factors Affecting Hemoglobin Levels7 Several factors that affect haemoglobin levels are iron adequacy in the body and iron metabolism. Effects of Hemoglobin on Growth and Development [21] - Nutritional factors were contributing to decreased growth and development of children are anaemia, a haemoglobin level lower than the average value. Anaemia that is commonly found in Indonesia, is caused by iron deficiency. The incidence of iron deficiency anaemia is common in children in developing countries, with a prevalence of $50 \%$ [22]. Iron is an essential substance as an electron transmitter system in mitochondria and is needed in myelin synthesis [23]. Anaemia can inhibit the growth and development of children, which has a severe impact on the long term because, in anaemia, the oxygen intake throughout the body is disrupted. In addition, disturbed oxygen intake also causes neurological problems, social interactions, and impaired concentration. Low haemoglobin levels can also cause a decrease in the development of children, especially children's intellectual intelligence. Anaemia conditions can make children have lower intellectual intelligence scores (10-15 points) and decreased learning abilities than healthy or normal children. Around 22 million children in Indonesia are affected by anaemia, which causes a loss of intellectual intelligence scores of 5 to 15 points, poor school performance, and a loss of potential future of up to $2.5 \%$.

\section{RESEARCH METHOD}

This research is non-experimental research using a correlation description 
Nia Reviani et.al. The relationship between hemoglobin concentration and physical growth and development of toddlers age 2-5 years in Malacca Village, Sumedang, West Java, Indonesia.

design. This study investigates the relationship between the variable haemoglobin concentration and the speed of physical growth and development in toddlers aged 2 to 5 years in the village of Malacca, Sumedang. The population in this study was all toddlers aged two years - 5 years in Malacca, Sumedang. The sampling technique in this study used purposive sampling, which was based on specific considerations made by the researcher, based on the characteristics or characteristics of the population that had been known previously. The samples in this study were 64 people consisting of 35 men and 29 women. The research will be carried out at Bakung I Posyandu, Bakung II Posyandu, and Bakung III Posyandu, Malacca village, Sumedang on January 29 January 31, 2019. The data used in this study is primary data. These namely data is directly taken from the object by the young research doctor. The data collection technique used to capture haemoglobin concentration with the speed of physical growth and development in toddlers aged two years - 5 years in the village of Malacca, Sumedang uses an examination technique using a hemoglobinometer. In this study, data processing activities will be carried out in the following activities: editing, coding, entry, and tabulating. The collected data is then analyzed by univariate analysis to provide an overview of the characteristics of each variable studied and bivariate analysis to prove whether or not there is a relationship between the independent and dependent variables using the SPSS (statistical package for the social sciences) application with chi-square test. In the chi-square test, it is stated to correlate with a $p$-value $<0.05$.

\section{RESULT AND DISCUSSION}

This research was conducted on a sample of toddlers aged two years - 5 years in January 2019 in Malaka Village, Sumedang Regency, with a sample of 64 people. Then from the results of the study obtained the following data:
Table 1. Distribution of respondents by sex of children two years -5 years in the village of Malacca, Sumedang

\begin{tabular}{|c|c|c|}
\hline Gender & Frequency & $\%$ \\
\hline Male & 35 & 54,7 \\
\hline Female & 29 & 45,3 \\
\hline Total & 64 & 100 \\
\hline
\end{tabular}

From the table above, it is clear that from 64 respondents, 35 people $(54.7 \%)$ were men and 29 people $(45.3 \%)$ were women.

Table 2. Distribution of respondents based on the relationship between Body Height category and haemoglobin concentration in children two years -5 years, Malacca village, Sumedang

\begin{tabular}{|l|l|l|l|l|l|l|}
\hline \multirow{2}{*}{$\begin{array}{l}\text { Deviasi Z-score } \\
\text { Body Height }\end{array}$} & \multicolumn{3}{|l|}{ Haemoglobin } & \multicolumn{2}{l|}{ Total } \\
\cline { 2 - 7 } & \multicolumn{2}{|c|}{ Anaemia } & \multicolumn{2}{|l|}{ Normal } & \multicolumn{2}{l|}{} \\
\cline { 2 - 7 } & $\mathbf{N}$ & $\mathbf{\%}$ & $\mathbf{N}$ & $\mathbf{\%}$ & $\mathbf{N}$ & $\%$ \\
\hline High & 0 & $00,0 \%$ & 1 & $100,0 \%$ & 1 & $100,0 \%$ \\
\hline Normal & 3 & $7,1 \%$ & 39 & $92,2 \%$ & 42 & $100,0 \%$ \\
\hline Short & 2 & $15,4 \%$ & 11 & $84,6 \%$ & 13 & $100,0 \%$ \\
\hline Very short & 2 & $25,0 \%$ & 6 & $75,2 \%$ & 8 & $100,0 \%$ \\
\hline Total & 7 & $10,9 \%$ & 57 & $89,1 \%$ & 64 & $100,0 \%$ \\
\hline
\end{tabular}

The data above is classified based on the Z-score of height on haemoglobin levels. The table shows that there are short children and concise children from 64 respondents, respectively 13 people $(20.3 \%)$ and $8(12.5 \%)$ while children who are classified as tall are one person $(1.6 \%)$ and with average height as many as 42 people $(65.6 \%)$. It can be concluded that the number of children with abnormal height is less than normal children.

Table 3. Distribution of respondents based on the relationship between body weight categories and haemoglobin concentration of children two years - 5 years in Malacca village, Sumedang

\begin{tabular}{|l|l|l|l|l|l|l|}
\hline \multirow{2}{*}{$\begin{array}{l}\text { Body Weight Z- } \\
\text { score deviation }\end{array}$} & \multicolumn{3}{|l|}{ Haemoglobin } & \multicolumn{2}{l|}{ Total } \\
\cline { 2 - 7 } & \multicolumn{2}{|c|}{ Anaemia } & \multicolumn{2}{|l|}{ Normal } & \multicolumn{2}{l|}{} \\
\cline { 2 - 7 } & $\mathbf{n}$ & $\mathbf{\%}$ & $\mathbf{n}$ & $\mathbf{\%}$ & $\mathbf{N}$ & $\%$ \\
\hline More & 0 & $0,0 \%$ & 1 & $100,0 \%$ & 1 & $100,0 \%$ \\
\hline Normal & 3 & $6,4 \%$ & 44 & $93,6 \%$ & 47 & $100,0 \%$ \\
\hline Less & 3 & $25,0 \%$ & 9 & $75,0 \%$ & 12 & $100,0 \%$ \\
\hline Very less & 1 & $25,0 \%$ & 3 & $75,0 \%$ & 4 & $100,0 \%$ \\
\hline Total & 7 & $10,9 \%$ & 57 & $89,1 \%$ & 64 & $100,0 \%$ \\
\hline
\end{tabular}

The table above shows the classification of body weight against haemoglobin levels. From the table, it can be concluded that as many as 47 people (73.4\%) had normal nutritional status, one person $(1.6 \%)$ had overweight status, twelve people $(18.8 \%)$ had poor nutritional status, and there were four people $(6,3 \%)$ with poor nutritional status. It proves that there are still children who are malnourished. In 
addition, 12 people with poor nutritional status can develop into malnutrition if not handled quickly and appropriately.

Table 4. Distribution of respondents based on the relationship between Body Mass Index and haemoglobin concentration of children two years -5 years, Malacca village, Sumedang

\begin{tabular}{|l|l|l|l|l|l|l|}
\hline \multirow{2}{*}{$\begin{array}{l}\text { BMI Z-score } \\
\text { deviation }\end{array}$} & \multicolumn{3}{|l|}{ Haemoglobin } & \multicolumn{2}{|l|}{ Total } \\
\cline { 2 - 7 } & Anaemia & \multicolumn{2}{|c|}{ Normal } & \multicolumn{2}{l|}{} \\
\cline { 2 - 7 } & $\mathbf{N}$ & $\mathbf{\%}$ & $\mathbf{N}$ & $\%$ & $\mathbf{N}$ & $\%$ \\
\hline Fat & 0 & $0,0 \%$ & 5 & $75,0 \%$ & 5 & $100,0 \%$ \\
\hline Normal & 7 & $13,0 \%$ & 47 & $87,0 \%$ & 54 & $100,0 \%$ \\
\hline Thin & 0 & $0,0 \%$ & 3 & $100,0 \%$ & 3 & $100,0 \%$ \\
\hline Very thin & 0 & $0,0 \%$ & 2 & $100,0 \%$ & 2 & $100,0 \%$ \\
\hline Total & 7 & $10,9 \%$ & 57 & $89,1 \%$ & 64 & $100,0 \%$ \\
\hline
\end{tabular}

The table above shows the number of respondents classified based on body mass index (BMI) for age, and this classification shows the physical condition of obese, regular, thin or very thin children. In 64 respondents, five people $(7.8 \%)$ were overweight, 54 people $(84.8 \%)$ were ordinary, the remaining five people were divided into three thin people $(4.7 \%)$ and skinny two people $(3.1 \%)$.

Table 5. Distribution of respondents based on the relationship between the results of Denver measurements and the haemoglobin concentration of children two years -5 years in the village of Malacca, Sumedang

\begin{tabular}{|l|l|l|l|l|l|l|}
\hline \multirow{2}{*}{ Denver } & \multicolumn{2}{|l|}{ Haemoglobin } & \multicolumn{2}{l}{ Total } \\
\cline { 2 - 6 } & \multicolumn{2}{|l|}{ Anaemia } & \multicolumn{2}{l|}{ Normal } & \multicolumn{2}{l|}{} \\
\cline { 2 - 6 } & n & \% & n & \% & n & \% \\
\hline N & 1 & $33,3 \%$ & 2 & $66,7 \%$ & 3 & $100,0 \%$ \\
\hline NO & 0 & $0,0 \%$ & 4 & $100,0 \%$ & 4 & $100,0 \%$ \\
\hline S & 6 & $10,5 \%$ & 51 & $89,5 \%$ & 57 & $100,0 \%$ \\
\hline Total & 7 & $10,9 \%$ & 57 & $89,1 \%$ & 64 & $100,0 \%$ \\
\hline
\end{tabular}

The table above shows the results of Denver on 64 respondents. A total of seven respondents had haemoglobin $<11 \mathrm{~g} / \mathrm{dL}$. The remaining 57 respondents had normal haemoglobin. From the results of the developmental examination using the Denver Developmental Screening Test II, as many as 57 respondents suspected of having developmental disorders, four children could not be examined, and only three respondents had average Denver scores.

From the results of the chi-square statistical test on 64 respondents, the pvalue $=0.452$ where the $\mathrm{p}$ value $>=0.05$ Then Ho is accepted and $\mathrm{Ha}$ is rejected, this shows that there is no significant relationship between haemoglobin concentration and body length at toddlers two years -5 years in the village of Malacca, Sumedang. From the results of the chi-square statistical test on 64 respondents, the $p$-value $=0.224$ where the $p$ value $>=$ 0.05 Then Ho is accepted and Ha is rejected, this shows that there is no significant relationship between haemoglobin concentration and body weight at toddlers two years -5 years in the village of Malacca, Sumedang.

From the results of the chi-square statistical test on 64 respondents, the pvalue $=0.693$ where the $p$ value $>=0.05$. Then Ho is accepted, and $\mathrm{Ha}$ is rejected. It shows no significant relationship between haemoglobin concentration and body mass index. In toddlers, two years - 5 years in the village of Malacca, Sumedang. From the results of the chi-square statistical test on 64 respondents, the $\mathrm{p}$-value $=0.360$ where the $\mathrm{p}$ value $>=0.05$ Then Ho is accepted and $\mathrm{Ha}$ is rejected, this shows that there is no significant relationship between haemoglobin concentration and development in toddlers two years - 5 years in Malaka Village, Sumedang. So it can be concluded in this study that there is no significant relationship between haemoglobin concentration and physical growth and development in toddlers aged two years - 5 years in Malaka Village, Sumedang.

Children whose height measurement is below -2 SD from the WHO standard are said to be stunted. Identify height by comparing a child's height with the height of children in the average population according to the same age and sex. Several current studies show that short children are strongly associated with poor education and lowerincome as adults. Stunting is more likely to grow into less educated, more impoverished, less healthy, and more susceptible to infectious diseases. From the measurement results in table 1 . It can be seen that the number of men and women in Malacca Village. In table 2. it is found that there is no relationship between height and haemoglobin concentration. Research conducted by Ayoya et al. said that children 
had a close relationship between stunting children and the incidence of anaemia [24].

The same thing can be seen in tables 3 and 4, there are 16 respondents with poor nutritional status and poor nutrition, and there are five respondents with skinny bodies. It is different from the research conducted by Soliman et al. in their research which said that children who have lower haemoglobin levels than average have a greater chance of experiencing growth disorders [25]. In table 4.5. the results of the developmental assessment using the Denver Developmental Screening Test II were classified based on their haemoglobin levels. In this Denver examination, the final result of Denver can be a suspect because, in the assessment, there is one component of the four components of the assessment. Denver is worth late or alert, and then the result will be suspect. In addition, expected results in this examination if the Pass values of the four components of the examination are met. There is a No Opportunity (NO) value because the child is not cooperative when the examination is carried out, such as crying, the child does not respond or does not want to do the examination.

The study results in table 5 show that there is no relationship between haemoglobin concentration and the development of children aged two years - 5 years in Malacca Village. This result is different from the research conducted by Pala et al. in their study, which was conducted in children aged six months to 72 months which tend to fail in aspects of language and movement coordination when compared to children who are not anaemic [26]. Akman et al. found slightly different results in their study involving 108 respondents aged six months-30 months. His research concluded that children with the same haemoglobin levels but with lower serum iron levels had lower Denver scores than respondents who had normal serum iron levels [27].

\section{CONCLUSION}

Based on the results and discussion of the research carried out in Malaka Village, Sumedang Regency, several conclusions can be drawn. They are a) there is a description of haemoglobin concentration, and there is no relationship between haemoglobin concentration and physical growth in toddlers aged two years 5 years, and b) the presence of description of haemoglobin concentration and the absence of a relationship between haemoglobin concentration and physical development in toddlers aged 2-5 years. Therefore, it is hoped that future studies using a larger sample to obtain more accurate data can be obtained, and then the Denver Development Test Screening can be carried out with direct observation of children to reduce the bias value by interviewing mothers.

\section{Acknowledgement: None}

\section{Conflict of Interest: None}

\section{Source of Funding: None}

\section{Ethical Approval: Approved}

\section{REFERENCES}

1. Devkota, M. D., Adhikari, R. K., \& Upreti, S. R. (2016). Stunting in Nepal: looking back, looking ahead. Maternal \& child nutrition, 12(Suppl 1), 257.

2. Adji, A., Asmanto, P., \& Tuhiman, H. (2019). Priority Regions for Prevention of Stunting. no. November.

3. Gashu, D., Stoecker, B. J., Bougma, K., Adish, A., Haki, G. D., \& Marquis, G. S. (2015). Stunting, selenium deficiency and anemia are associated with poor cognitive performance in preschool children from rural Ethiopia. Nutrition journal, 15(1), 1-8.

4. Perignon, M., Fiorentino, M., Kuong, K., Burja, K., Parker, M., Sisokhom, S., ... \& Wieringa, F. T. (2014). Stunting, poor iron status and parasite infection are significant risk factors for lower cognitive performance in Cambodian school-aged children. PloS one, 9(11), e112605. 
5. Rezaei, M., Karimi Torshizi, M. A., Wall, H., \& Ivarsson, E. (2018). Body growth, intestinal morphology and microflora of quail on diets supplemented with micronised wheat fibre. British poultry science, 59(4), 422-429.

6. Bechard, L., \& Puig, M. (2003). Body composition and growth. Nutrition in pediatrics. London: BC Decker, 32-51.

7. Yamazaki, K., Kawamoto, T., Fujinami, H., \& Shigemitsu, T. (2001). Investigation of ELF magnetically induced current inside the human body: Development of estimation tools and effect of organ conductivity. Electrical Engineering in Japan, 134(2), 1-10.

8. Cole, T. J. (2009). Growth and organ development. Breast-Feeding: Early Influences on Later Health, 1-13.

9. Gladstone, M., Lancaster, G. A., Umar, E., Nyirenda, M., Kayira, E., van den Broek, N. R., \& Smyth, R. L. (2010). The Malawi Developmental Assessment Tool (MDAT): the creation, validation, and reliability of a tool to assess child development in rural African settings. PLoS medicine, 7(5), e1000273.

10. Rubio-Codina, M., Araujo, M. C., Attanasio, O., Muñoz, P., \& GranthamMcGregor, S. (2016). Concurrent validity and feasibility of short tests currently used to measure early childhood development in large scale studies. PLoS One, 11(8), e0160962.

11. Monsma, E. V., Miedema, S. T., Brian, A. S., \& Williams, H. G. (2020). Assessment of gross motor development in preschool children. In Psychoeducational Assessment of Preschool Children (pp. 283-319). Routledge.

12. Jensen, F. B. (2009). The dual roles of red blood cells in tissue oxygen delivery: oxygen carriers and regulators of local blood flow. Journal of Experimental Biology, 212(21), 3387-3393.

13. Mairbäurl, H. (2013). Red blood cells in sports: effects of exercise and training on oxygen supply by red blood cells. Frontiers in physiology, 4, 332.

14. Kanias, T., \& Acker, J. P. (2010). Biopreservation of red blood cells-the struggle with hemoglobin oxidation. The FEBS journal, 277(2), 343-356.

15. Jorge, S. E., Ribeiro, D. M., Santos, M. N., \& de Fátima Sonati, M. (2016).
Hemoglobin: Structure, synthesis and oxygen transport. In Sickle cell anemia (pp. 1-22). Springer, Cham.

16. Jahn, D., \& Heinz, D. W. (2009). Biosynthesis of 5-aminolevulinic acid. In Tetrapyrroles (pp. 29-42). Springer, New York, NY.

17. Yang, P., Liu, W., Cheng, X., Wang, J., Wang, Q., \& Qi, Q. (2016). A new strategy for production of 5-aminolevulinic acid in recombinant Corynebacterium glutamicum with high yield. Applied and environmental microbiology, 82(9), 2709-2717.

18. Ke, H., Sigala, P. A., Miura, K., Morrisey, J. M., Mather, M. W., Crowley, J. R., ... \& Vaidya, A. B. (2014). The heme biosynthesis pathway is essential for Plasmodium falciparum development in mosquito stage but not in blood stages. Journal of Biological Chemistry, 289(50), 34827-34837.

19. Lee, M. J., Kim, H. J., Lee, J. Y., Kwon, A. S., Jun, S. Y., Kang, S. H., \& Kim, P. (2013). Effect of gene amplifications in porphyrin pathway on heme biosynthesis in a recombinant Escherichia coli. Journal of microbiology and biotechnology, 23(5), 668-673..

20. Shaw, J. G., \& Friedman, J. F. (2011). Iron deficiency anemia: focus on infectious diseases in lesser developed countries. Anemia, 2011.

21. Larson, L. M., Kubes, J. N., RamírezLuzuriaga, M. J., Khishen, S., H. Shankar, A., \& Prado, E. L. (2019). Effects of increased hemoglobin on child growth, development, and disease: a systematic review and meta-analysis. Annals of the New York Academy of Sciences, 1450(1), 83-104.

22. World Health Organization. (2011). Prevention of iron deficiency anaemia in adolescents (No. SEA-CAH-02). WHO Regional Office for South-East Asia.

23. Jeon, Y. M., Kwon, Y., Jo, M., Lee, S., Kim, S., \& Kim, H. J. (2020). The Role of Glial Mitochondria in $\alpha$-Synuclein Toxicity. Frontiers in cell and developmental biology, 8, 1297.

24. Ayoya, M. A., Ngnie-Teta, I., Séraphin, M. N., Mamadoultaibou, A., Boldon, E., SaintFleur, J. E., ... \& Bernard, S. (2013). Prevalence and risk factors of anemia among children 6-59 months old in Haiti. Anemia, 2013. 
Nia Reviani et.al. The relationship between hemoglobin concentration and physical growth and development of toddlers age 2-5 years in Malacca Village, Sumedang, West Java, Indonesia.

25. Helmyati, S., Rahayu, E. S., Kandarina, B. J. I., \& Juffrie, M. (2020). No difference between iron supplementation only and iron supplementation with symbiotic fermented milk on iron status, growth, and gut microbiota profile in elementary school children with iron deficiency. Current Nutrition \& Food Science, 16(2), 220-227.

26. Pala, E., Erguven, M., Guven, S., Erdogan, M., \& Balta, T. (2010). Psychomotor development in children with iron deficiency and iron-deficiency anemia. Food and nutrition bulletin, 31(3), 431-435.

27. Akman, M. E. H. M. E. T., Cebeci, D. İ. L. Ş. A. D., Okur, V., Angin, H., Abali, O., \&
Akman, A. C. (2004). The effects of iron deficiency on infants' developmental test performance. Acta Paediatrica, 93(10), 1391-1396.

How to cite this article: Reviani N, Patriawati KA. The relationship between hemoglobin concentration and physical growth and development of toddlers age 2-5 years in Malacca Village, Sumedang, West Java, Indonesia. Int J Health Sci Res. 2021; 11(8): 237-244. DOI: https://doi.org/10.52403/ijhsr. 20210833

$* * * * * *$ 